\title{
How Conservative Was the Holy Alliance Really? Tsar Alexander's Offer of Radical Redemption to the Western World
}

\author{
Beatrice de Graaf
}

\section{A Celebration of Holy Magnanimity}

At four o'clock in the morning on 10 September 1815, the Allied forces engulfed the plains of Vertus, northeast of Paris. ${ }^{1}$ The Russian Tsar Alexander, flanked by the emperor of Austria and the King of Prussia, the Duke of Wellington, and other princes positioned themselves on top of Mont-Aimé, arising from the plains. Thousands of spectators were drawn from Paris to watch the spectacle of over 150,000 soldiers spreading like crescents over fields, punctuated by the sound of 540 canons. According to a female spectator: "Owing to the heat, one man dropped down in a fit just at the saluting-point, but otherwise all went off with éclat." ${ }^{2}$ The next day transposed this military spectacle into an almost eschatological event. That day, in honor of Saint Alexander Nevski, Tsar Alexander staged an ecumenical mass. For the onlookers, the sight of 150,000 soldiers kneeling before seven altars, organized in seven squares was unbelievably impressive. For Barbara Juliane (Julie) von Krüdener, Tsar Alexander's pietist religious friend, it was a truly spiritual experience. ${ }^{3}$

Apart from this spectacular demonstration of Allied and Russian power and magnanimity toward the French people, a far more momentous event, but less visibly one, unwound behind the scenes: the preparation of a "secret plan for the benefit of Europe" —originating from Tsar Alexander and his entourage. This plan, which became known as the Holy Alliance, has entered history textbooks as a method to enact the repression of reformist and liberal ideals and

\footnotetext{
1 The research leading to this chapter received funding from the ERC under the European Union's Seventh Framework Programme (FP/2007-13) / ERC Grant Agreement n.615313.

2 Richard Edgcumbe (ed.), The Diary of Frances Lady Shelley, 1787-1817 (New York: 1912), 158-59.

3 See Clarence Ford (ed.), The Life and Letters of Madame de Krudener (London: 1893), 212.
} 
return to the ancien régime. ${ }^{4}$ In short, it has been referred to as a blueprint for restoration and conservation rather than for renewal. ${ }^{5}$

I argue here that Alexander's Holy Alliance was far less conservative and far more revolutionary than it was later understood to be. To make this point, I first unpack how this "secret plan" came to be understood as "conservative" and how this reading of the Holy Alliance Treaty was influenced by latter-day interpretations and machinations far more than by its concrete substance at the time. Subsequently, I will break down the origins and constitutive elements of the plan in order to demonstrate that it was a revolutionary amalgam of Christian pietism, semi-scientific Enlightenment theories, and a dose of modern, bureaucratic state centralism. Based on new archival evidence, we can now point to the involvement of both Prussian security experts and French semi-scientist scholars in drafting the plan for the Holy Alliance. The Holy Alliance contained conservative ingredients, but the liberal and provocative elements stood out - these were however suppressed within a few years by political appropriations by other statesmen. ${ }^{6}$

The Holy Alliance was the treaty Tsar Alexander presented in draft form to his fellow royals on 22 September 1815, three months after the victorious battle of Waterloo and the onset of the joint Allied occupation of France in early July 1815. The Allied princes resided in the French capital until a peace settlement was concluded, whereas their ministers would remain in conference for the next five years-as long as the military occupation of France was thought to last. Each of the Allied monarchs, including the British Regent, signed the Holy Alliance Treaty on 26 September, and in the next months, all other secondary and smaller European powers subscribed to the Treaty as well. The Treaty contained - at first glance - a lofty and high-spirited appeal to the princes, the governments, and the peoples of Europe to abandon the power politics

4 See, for example, Alan John Percivale Taylor, The Struggle for Mastery in Europe, 1848-1918 (Oxford: 1954), 2; Henry Kissinger, Diplomacy (New York: 1994), 83-85; Hajo Holborn, "Russia and the European Political System," in Russian Foreign Policy: Essays in Historical Perspective, ed. Ivo J. Lederer (New Haven, CT: 1962), 377-409, here 383.

5 See especially Philipp Menger, Die Heilige Allianz: Religion und Politik bei Alexander I. (1801-1825) (Stuttgart: 2014).

6 This chapter is based on the research for my monograph, Beatrice de Graaf, Fighting Terror after Napoleon (Cambridge: 2020). In Dutch, Tegen de terreur: Hoe Europa veilig werd na Napoleon (Amsterdam: 2018). 
of yore and subscribe to a new system of international relations based on Christian-inspired brotherly love.

Immediately upon announcement and presentation of the Holy Alliance Treaty, misunderstandings and misinterpretations arose. When Alexander called at Castlereagh's Paris residence to share his European credo with him and Wellington, they had to do their best to remain serious: "It was not without difficulty that we went through the interview with becoming gravity", Castlereagh reported to Prime Minister Liverpool. "The fact is that the Emperor's mind is not completely sound." In addition, on 28 September, Castlereagh simply discarded the Treaty as "this piece of sublime mysticism and nonsense". 8 Prince Metternich similarly is said to have quipped that, to him, the Treaty was nothing more than a laut tönendes Nichts. It was nothing more than "the expression of the Emperor Alexander's mystical sentiments, and the application of these Christian principles to politics". 9

Yet it is too simple for historians nowadays to uncritically follow these early qualifications and dismiss Alexander as a religiously derailed autocrat. First, Alexander was doing exactly what Castlereagh had suggested in the Allied Council, the forum convened to discuss the future of France and design a security arrangement for Europe as a whole. It is just that his doing so turned out to be much more religious and grandiose than the British had anticipated..$^{10}$ Second, by uncritically reiterating Castlereagh's and Metternich's qualifications, we lose sight of what really happened. The original draft of the Holy Alliance was far less autocratically inspired and backward looking than historical representation suggests. The reason for this framing of the Treaty is not illogical or completely unfounded: the contemporaries themselves tried to steer the interpretation in a specific direction. Most notably, Prince Metternich tried to acquire the Deutungshoheit over the Treaty almost immediately upon its dissemination.

From 1815 onward, together with Friedrich Gentz, ${ }^{11}$ and in full communication with Wellington, the Austrian chancellor consistently tried to rewrite and

7 Castlereagh to Liverpool, 28 September 1815, cited in Arthur Wellesley (ed.), Supplementary Dispatches and Memoranda of Field Marshal Arthur Wellesley, 1st Duke of Wellington [abbreviated as WSD ], vol. 11 (London: 1864), 176-77.

8 Ibid., 175 .

9 Richard Metternich, Memoirs of Prince Metternich, 1773-1835 (New York: 188o-82), 210-12; Guillaume de Bertier de Sauvigny, "Sainte-Alliance et Alliance dans les conceptions de Metternich," Revue Historique 223 (1960), 249-74, here 251.

10 See John Bew, Castlereagh: A Life (Oxford: 2012), 410-11.

11 Although Gentz was initially somewhat more open to liberal influences. See Raphaël Cahen, Friedrich Gentz, 1764-1832: Penseur post-Lumières et acteur du nouvel ordre européen (Berlin: 2017). 
appropriate the Holy Alliance and turn it into a ploy for conserving the existing legal order and legitimizing military interventions necessary to uphold that order, as in Spain or Greece. To Wellington, Metternich's ambassador Vincent asserted in January 1819:

A powerful antidote in the person of the Emperor can exist with regard to the principles that everywhere threaten the social order, busying him in the spirit of the Holy Alliance, which will deaden the effect of his troubling politics and will contribute to the continuance of conservative principles of general order. ${ }^{12}$

In addition, Metternich himself followed this manipulative line further when he wrote in 1821 to Alexander that all monarchs need to "oppose this plan of universal destruction" and to work for "the preservation [la conservation] of everything legal existing". ${ }^{13}$ In reality, this meant that Metternich successfully deflected Alexander from bringing forward his ideas for a unity of peoples, of constitutional reforms, and of invading the Balkans to deliver oppressed Christians and bring in liberal rule.

Two influential contemporaries noticed Metternich's rewriting of the Treaty's history and manipulating Alexander's heritage (in his lifetime and then after his death). Benjamin Constant, in France, wrote in Le Courier Français, on 28 October 1822:

Skilled diplomats ... seized this Holy Alliance to ... destroy the independence of the peoples in the name of the independence of sovereigns, to employ in the war of absolute power against freedom the forces, which it had dedicated to the maintenance of peace. By changing its nature in this way, the Holy Alliance also changed its leader ... it is now Austria and M. de Metternich who lead the European coalition ... The philanthropic character and the pious direction chosen by the emperor Alexander are nothing more than a distant memory, without any influence. ${ }^{14}$

And Johann Wolfgang von Goethe, in conversation with his friend Johann Peter Eckermann, on 3 January 1827 struck a similar chord, when he remarked

12 Letter Baron de Vincent to Arthur Wellesley, first Duke of Wellington, 4 January 1819, in WSD, vol. 1, 2-3.

13 Metternich to Alexander, Laibach, 6 May 1821, in Richard Metternich (ed.), Memoirs of Prince Metternich, 1815-1829, vol. 3 (London: 1881), 535-42, here 538.

14 Le Courier Français, 28 October 1822. 
that "nothing greater and more benevolent for humanity as a whole has been invented besides the Holy Alliance". 15

In short: first, Metternich appropriated the Alliance in the years after its conception, used it to bind Alexander to his continental conservative policies, and prevent him from letting loose all kinds of libertarian, reformist ideas, and after 1822, turned it into a vehicle for his own, more short-term preservationist and conservative ideals. ${ }^{16}$ Then, in the public understanding and interpretation, the Tsar's original ideas and the Treaty itself were conflated with this conservative instrumentalization by Metternich and Austria's security police. The tragedy is that Metternich never really understood Alexander's real intentions, the real content of the Treaty, and only saw it as a tactical instrument. ${ }^{17}$ It is therefore high time to consign the Holy Alliance to history by going back to the Tsar's original plans and the inspirations that flowed into the Treaty.

Over the last years, inspired by the bicentennial of the Congress of Vienna, more works have been written about Tsar Alexander-most importantly the recent biography by Marie-Pierre Rey. ${ }^{18}$ The Holy Alliance, the culmination of the Tsar's plans for Europe completed just before his impending departure for Russia, can only be understood as the crown on longer term development of European affairs and a broader cultural climate of European renewal and regeneration, ${ }^{19}$ as well as on the Tsar's growing sense of mission in the years since 1801 , the year when his father was murdered and he was appointed Tsar and Napoleon's coronation as emperor of France.

This development was nourished by three sources: Alexander's upbringing as a child of the Enlightenment, his conversion to pietism, and his almost mythological victory over Napoleon. According to his biographer, Marie-Pierre Rey, Alexander was a child of the Enlightenment, a lonely optimist, raised by

15 Johann Peter Eckermann, "Gespräche mit Goethe," 3 January 1827, in Goethes Gespräche, vol. 6, ed. Woldemar von Biedermann (Leipzig: 1890), 1070.

16 See also Henry A. Delfiner, "Alexander I, The Holy Alliance and Clemens Metternich: A Reappraisal," East European Quarterly 37 (2003), 127-5o, here 146.

17 Bertier de Sauvigny makes this point as well, Bertier de Sauvigny, "Sainte-Alliance," 256.

18 Marie-Pierre Rey, Alexander I: The Tsar who Defeated Napoleon (DeKalb: 2012).

19 See especially Matthijs Lok, "The Congress of Vienna as a Missed Opportunity: Conservative Visions of a New European Order after Napoleon," in Securing Europe after Napoleon: 1815 and a New European Security Culture, ed. Beatrice de Graaf, Ido de Haan, and Brian Vick (Cambridge: 2019$), 5^{6-71 .}$ 
his extremely progressive Swiss tutor Frédéric-César de Laharpe and groomed for the job of tsar by an ambitious grandmother, Catherine the Great. Rousseau, Montesquieu, and Voltaire were his bedtime reading. His mother was a German princess who did much for charitable organizations; his father, Tsar Paul I, was a paranoid tyrant who was murdered by a camarilla from his court in 1801 . Alexander was probably aware of a conspiracy against his father, but was nonetheless surprised by his murder and felt guilt and remorse about this turn of events for the rest of his life. ${ }^{20}$ But the 23-year-old heir to the throne courageously set about to put his own ideals into practice, to further modernize Russia, try to abolish serfdom, work toward designing a new constitution, and colonize and make the newly annexed territories in the Caucasus and Crimea productive. Yet, Russia's realities frustrated and quashed most all of his plans for reform. ${ }^{21}$

Thus, when he started his reign, Alexander was already a tormented soul. The Tsar tried to wrestle his inner demons by stepping up his good deeds, such as trying to redeem his own people from backwardness and poverty. He also joined forces with the other allied countries, to together confront the "new antichrist," Napoleon, starting in 1806. Jumping a few years into the future of his increasingly challenged reign, we find Alexander in front of an almost apocalyptical panorama-Moscow in flames. There, Alexander found a confirmation of his divine calling:

In the end, the burning of Moscow illuminated my soul, and the judgment of God on the frozen battlefield filled my heart with a warmth of faith that it had never felt before. ... Henceforth I learned to understandand I understand now-His will and His law, and the decision to devote my person and my reign only to Him and to His glory, matured and was fortified in me. Since that time, I have become another man; to the deliverance of Europe from ruin, I owe my own salvation and my deliverance. ${ }^{22}$

He brought this offer of mercy and redemption with him in the wake of his march into Western Europe. ${ }^{23}$ On 31 March, "Divine Providence" provided—at

\footnotetext{
20 See for literature on trauma in the Age of Revolutions, e.g. Barry M. Shapiro, Traumatic Politics: The Deputies and the King in the Early French Revolution (University Park, TX: 2009). Alexander Poesjkin, "Bova" (1814). Cited in Liubov Melnikova, "Orthodox Russia against 'Godless' France: The Russian Church and the 'Holy War' of 1812," in Russia and the Napoleonic Wars, ed. Janet M. Hartley, Paul Keenan, and Dominic Lieven (Basingstoke: 2015), 179-95, here 191.

22 Cited in Rey, Alexander I, 256.

23 Ibid., 264.
} 
least that is what Alexander believed and was told to believe by his Christian friends - what he had been yearning for: proof of atonement accepted, a calling confirmed. The man who had cried over the smoking ruins of Moscow, now drew loud cheers as he entered the French capital, flanked by the Prussian king and General Schwarzenberg (on behalf of the Austrian emperor). He was the elu and conduit par Dieu, it was "Divine Providence"24 that put him at the forefront of the allied victors. The Tsar wore his Chevalier Guard regiment's uniform, rode his gray horse Mars and was escorted by the exotic Cossack Life-Guards on their small, fast horses. According to Alexander's aidede-camp Mikhailofsky-Danilefsky, the welcome was warm and the troops behaved well. ${ }^{25}$

Even though Napoleon had invaded his kingdom, murdering thousands and setting cities ablaze, Alexander wanted to a be a conqueror who would have Paris fall at his feet-in order to subsequently pardon and save the city. Without waiting for the others, but on behalf of the other three allied powers, he proclaimed his divinely inspired, peace project for France and Europe:

The sovereigns proclaim: ... That they respect the integrity of ancient France such as it existed under its legitimate kings; they may even do more because they still profess the principle that for the happiness of Europe, France must be great and strong; that they will recognize and guarantee the constitution that the French nation will adopt. They thereby invite the Senate to designate a provisional government that will be able to answer the needs of the administration and prepare a constitution that suits the French people. ${ }^{26}$

And indeed, at the insistence of the Tsar, Paris and the country were protected against pillaging and looting, and the French king and government were nudged into making haste to offer a new constitution to their people. ${ }^{27}$ The French writer, diplomat, and romantic Bourbon supporter François-René Chateaubriand was deeply impressed. "This first invasion by the allies remains

\footnotetext{
24 Roxandre Stourdza to Alexander, 15 December 1814, cited in ibid., 97.

25 See A. Mikhailofsky-Danilefsky, History of the Campaign in France in the Year 1814 (London: 1839), 383-9o; Bew, Castlereagh, 349.

$26 \mathrm{NN}$, Alexandrana ou bons mots et paroles remarquables d'Alexandre Ier (Paris: 1815), 47. Cited in Rey, Alexander I, 268-69. See also Cobbett's Political Register 25 (1814), 50o. The Monthly Magazine; or British Register 37 (1814), 366.

27 See Henri Houssaye, 1814 (Paris: 1888), 537n1, 549-672; "Alliierte Dispositionen in Sachen Truppenkantonierungen in Frankreich," 10 April 1814, Geheimes Staatsarchiv Preußischer Kulturbesitz, Berlin [GStA PK], III. HA, I. Nr. 862.
} 
unparalleled in the annals of the world: order, peace and moderation reigned everywhere ... The vanquished could be taken for the victors, who trembled with their success and seemed to excuse themselves for it."28 Joyous shouts reverberated through the streets of Paris in March and April, Vive Alexandre, vivent les alliés. ${ }^{29}$

Of course, alongside all pietist and peaceful proclamations, Alexander was also driven by immense ambitions. His ambition was to continue the work of his grandmother - to elevate the Russian nation and position it on the international map. Besides Britain, only Russia exited the Napoleonic wars with her fleet intact and her dominance on the continent augmented. With Alexander, Russia once again had a tsar on the throne who, in line with Peter the Great and Catherine the Great, laid claim to a role for himself in European politics and who also thought and lived like a European. Nevertheless, these very mundane political ambitions went hand in glove with a truly heartfelt piety. Alexander's imperial aspirations were inspired by a robust sense of calling and defined by strict limitations: he did not venture beyond Russia's sphere of influence in the east, delineated by Poland. In the rest of Europe, not territorial aggrandizement, but staging a role as spiritus rector of a new just order was his aim in life-including the invention of a masterplan that captivated this idea of the renewal of France and Europe.

\section{A Plan for the Security and Salvation of Europe - with Help from} the Prussians

Arriving on 10 July, Alexander sought out a hotel at the Rue du Faubourg St. Honoré for his headquarters (close to the British headquarters). There, he invited his pious and considered by many almost fanatically religious friend Julie, the Baroness von Krüdener, with her daughter to stay in a city palace adjacent to his at number 35 the Hôtel Montchenu. They received the Russian emperor almost daily in their religious salon and succeeded in convincing him that his calling was not yet over. He was to be the redeemer of France and Europe: to lead the French people away from revolutionary convulsions, he

\footnotetext{
28 François-René Chateaubriand, Mémoires d'outre-tombe, 12 vols. (Paris: 1973 [1849]), vol. 2, 251. English translation in Rey, Alexander I, 268.

29 See Thomas McNally, "Das Rußlandbild in der Publizistik Frankreichs zwischen 1814 und 1843," Forschungen zur Osteuropäischen Geschichte 6 (1958), 82-170, here 9o-95; Houssaye, 1814, $561-72$.
} 
was the "second Abraham" 30 that needed to prepare France for a departure out of their heathen ways towards the promised land, and save Europe as a whole. Alexander's salvific visions were infused and strengthened by his Enlightenment beliefs and ideals. During a visit to the Académie française, he could not hide his emotions; walking through France's temple of literature and philosophy, the Tsar could not help but realize that the names honored along the Neva River in St. Petersburg had their home here along the Seine. ${ }^{31}$ At the same time, it was he who had conquered his French idols and to him they now bowed in allegiance. It was to the peoples of France, and of Europe, to whom he felt an obligation to bestow upon them a plan for peace and security that would last.

Between 10 July and 20 September 1815, lengthy and tiresome negotiations over the Second Peace Treaty of Paris (the peace settlement referred to above) took place among the four dominant Allied powers. Their council, the Allied Council of Ministers, convened daily at the Hôtel de Charost, embassy of Britain, and was presided over by Castlereagh as British Foreign Minister, and Wellington, as supreme commander of the joint Allied forces. Against this backdrop, the Holy Alliance was delivered. For Alexander, these negotiations on fortresses, arrears payments, borders, and the relocation of troops went far too slowly. The morass of nitty-gritty details and paragraphs consumed too much time and energy. To the Tsar, it was paramount to bring his troops back home before the winter set in and leave Paris as soon as possible. It was however equally pivotal to find a catchall solution, a quick fix to solve his dilemma: how to leave France secured and protected from disturbances and turmoil for the future?

This is where new archival findings come in. The Holy Alliance is mostly attributed to Alexander's pietist and orthodox advisers: the Baroness von Krüdener, or, as Stella Ghervas argues, his Greek orthodox confidents, Alexandre Stourdza and his pious sister Roxandre..$^{32}$ Evidently, the Stourdzas were among his most loyal, faithful, and persistent friends and advisers, and the Baroness von Krüdener was certainly part of his inner circle in $1813^{-15}$ as well. Yet, the Holy Alliance Treaty found additional and more modern and enlightened

$30 \quad$ Madame de Krüdener, 11 July 1815, as cited in Francis Ley, Alexandre ${ }^{e r}$ et sa Sainte-Alliance (1811-1825). Avec des documents inédits (Paris: 1975), 131. See also Ford, Life and Letters of Madame de Krudener, 189, where Madame de Krüdener describes Alexander as an "angel" and a "Christian hero".

See Albertz Beugnot (ed.), Mémoires du Comte Beugnot, Ancién Ministre (1783-1815) (Paris: 1868), 143-44.

32 See Stella Ghervas, Réinventer la tradition: Alexandre Stourdza et l'Europe de la Sainte Alliance (Paris: 2008). 
parents in Paris in July 1815. They helped the Tsar accelerate the process and produce a Treaty before the end of September and meet his deadline.

First, Tsar Alexander looked for, and found, hefty support in an old acquaintance and civil servant of his: the Prussian reformist bureaucrat Justus von Gruner. On the Prussian Chancellor Karl August von Hardenberg's recommendation, the Allied Council appointed Gruner as head of both the Allied secret police (Verbündetenpolizei) in France and the occupational police force in Paris. Born in 1777 in Osnabrück, legal student Gruner made a career as a careful and hardworking public servant in the newly conquered Polish areas, especially in the province of Posen, where he worked for an organization that helped Germans settle there. He introduced reforms on criminal law and the prison system and came with new ideas on the centralization and organization of public order and morality. Gruner was a modern-day professional: he combined his fervency for modernizing bureaucracy with a passionate and even romantic position on good manners and morals. ${ }^{33} \mathrm{He}$ was appointed director of the police force in Berlin in 1809, as the Prussian reformers Karl Freiherr vom Stein and Hardenberg were both impressed by his unremitting commitment, patriotism, and penchant for administrative innovation. In Berlin, Gruner made a name for himself by centralizing the police, extending their jurisdiction to Berlin's suburbs, reforming the fire department and the city's waste management services, and introducing all sorts of measures to combat corruption. Meanwhile, he was appointed to the Secret Council of State and as chief of "higher police" in Prussia. Intermittently, Gruner was invited by Tsar Alexander in 1812 to build an anti-Napoleonic spy network from Prague (where Metternich arrested him, since Austria was still an ally of France). After Austria joined the Sixth Coalition in 1813, Gruner was released and immediately appointed governor of the general government of the now occupied duchy of Berg.

In 1815, thanks to his excellent contacts with Stein, Chancellor Hardenberg and Tsar Alexander, Gruner was an obvious candidate for the Verbündetenpoli$z e i$. According to Hardenberg, there was no better candidate imaginable. ${ }^{34} \mathrm{He}$ arrived on 9 July charged by the Allies to establish a General Directorate of

33 Cf. Justus Gruner, Versuch über die rechte und zweckmäßigste Einrichtung öffentlicher Sicherheitsinstitute und deren Verbesserung (1802); Idem, Meine Wallfahrt zur Ruhe und Hoffnung oder Schilderung des sittlichen und bürgerlichen Zustandes Westphalens am Ende des 18. Jahrhunderts (1802).

34 See Kurt Zeisler, "Justus von Gruner: Eine biographische Skizze," in Berlin in Geschichte und Gegenwart, ed. Werner Breunig and Uwe Schaper (Berlin: 1994), 81-105. 
Police as well as a military police force. ${ }^{35}$ Gruner was responsible for assisting and keeping an eye on the French administration, equitably distributing among the Allies the income from the occupied territories, and insuring the safety of the occupying forces.

Among his methods was the establishment of a solid network of spies reporting on the esprit public, as well as on fausses nouvelles that ran around France and its capital that hot summer. Siding with Gruner, Alexander was far less optimistic about the political and social tendencies in France than his British and Austrian colleagues seemed to be. Alexander and Gruner felt, based on the latter's daily intelligence briefs on the state of the French public mind, that the Duke of Wellington's assessment was too rosy; he was too "assured and confident about the present situation - which is certainly his right as a great hero, but to me does not seem well-founded". Gruner believed the threat of an insurgency was still far too great- "a moment can devour us". ${ }^{36}$ He had been receiving a steady stream of reports from his agents that Joseph Fouché-still police minister until 2o September-surrounded himself exclusively with "die-hard Bonapartists" and that he was replacing "reliable," that is, royalist, civil servants and administrators with "scoundrels" and "partisans du système anarchique". ${ }^{37}$

Where Gruner applied his skillful techniques of centralized intelligence and monitoring, Alexander intended to take the securing of France a substantial step further. He wanted to infuse Gruner's Allied police apparatus with a moral framework that would channel the new spirit, a new ideal for a restored, enlightened, wisely governed France. The Holy Alliance had to be the spirit in Gruner's bureaucratic machine.

Behind the scenes, that plan was indeed unfolding. At the end of August, a "secret society" of French royalists, mesmerists, and the Tsar himself was established. Now, the time was ripe to involve the Prussians and the Allied security service as well. Against that background, Gruner received a very special offer on 24 August. One of Gruner's agents, a certain Chr. Deliège, a lawyer to the king's council and the court of cassation as well as a loyal royalist, invited Gruner to be part of an association to save the honor of France and the civilization of Europe from the "scourge of our time"-Bonapartism and revolutionary rebellion.

35 The official order, signed by the four Allied powers, was issued on 8 August at Gruner's request. Letter from the Administrative Committee of the Allied Council to Gruner, 8 Augustus 1815, GStA PK, Nr. 86.

36 Gruner, Report of a conversation with Wellington, 24July 1815, GStA PK, Nl. Hardenberg $10 a$.

37 Reports to Gruner, between 13 and 20 August, GStA PK, Nl. Gruner Nr. 86; Gruner, Report of a conversation with Wellington, 24 July 1815, GStA PK, Nl. Hardenberg $10 a$. 
According to Deliège, the French ministers, most notably Fouché, were not attempting to "heal" the French nation, but were bent on further enflaming the "hot fever that had pushed the French by the millions into the field of carnage". As reported by Deliège, Alexander felt that the revolution was bound to return once the Allies had left, so something needed to be done. Gruner was therefore invited, together with the other "Heroes of Virtue" - Field Marshal August von Gneisenau, the above mentioned Hardenberg, and the Prussian minister Wilhelm von Humboldt - to assist with the tsar's plan. ${ }^{38}$ Such an invitation was too tempting and Gruner agreed to meet the group at the place of a certain Nicolas Bergasse. ${ }^{39}$ By doing so, Gruner entered an extremely remarkable secret society, of which the third pillar, next to Alexander's pious friends at the Krüdener salon, the Prussian bureaucrats and spies around Gruner himself, consisted of a group of semi-scientists around Bergasse and Deliège who called themselves Mesmerists.

\section{A Mesmerizing Perspective}

Alexander's secret society of friends consisted of an unlikely and irregular group of pietists, semi-scientists, Parisian salonnières, and Prussian bureaucrats. In his quest for a rejuvenating of a European spirit, surpassing the confessional boundaries of religious orders-Catholic, Protestant, Orthodox alike-new scientific ideas, bureaucratic rigor, and enlightened wisdom were called for in equal measure. In Paris, Alexander had found this unique combination in the "religious salon" hosted by Madame de Krüdener and frequented by, among others, Chateaubriand, Benjamin de Constant, and Nicolas Bergasse. ${ }^{40}$

Bergasse, the son of a wealthy merchant family, had come under the spell of the Austrian physician-charlatan Franz Mesmer before the French Revolution. This Austrian doctor taught that a single universal fluid surrounds and permeates all things, linking the cosmos, the earth, planets, and people, such that we can communicate through "animal magnetism" (as opposed to mineral magnetism) with our environs and fellow human beings. He claimed that when this communication was disturbed (by obstacles), disharmony arose, and the system became unbalanced. Through "crises", convulsions and special séances,

38 Letter from Deliège to Gruner, 24 August 1815, GStA PK, Nl. Gruner Nr. 86, 29-33.

39 Letter from Gruner to Deliège, 3 September 1815, GStA PK, Nl. Gruner Nr. 86, 47.

40 For the influence of such transnational networks and salons, see Brian Vick's chapter in this volume. See for more information on this "religious salon": Ford, Life and Letters of Madame de Krudener, 182-88. 
some people were able, as "magnetizers", to remove the obstacles and restore the harmony. This scientific theory and practice solicited so much acclaim and criticism that both the French and the British Royal Academies initiated a thorough assessment to establish whether mesmerism could be accepted as science. This elevated mesmerism even further into public and scientific awareness. While Franz Mesmer primarily applied his theory to nature, developing a kind of health therapy with it, Bergasse and his associates also applied mesmerism to politics - where obstacles were causing similar disharmony to spread. At the time of the French Revolution, this strand of radical mesmerism had many followers, including Lafayette, Jacques-Pierre Brissot, and Jean-Louis Carra. But Bergasse was the most fervent disciple, and his financial means and organizational talent made it into a veritable cult. ${ }^{41}$ We have to realize that, around 1800 , it was by no means unusual to connect physical phenomenasuch as electricity, magnetism, and physical disorders - with each other in a kind of holistic theory. Science, superstition, religion, and transcendent theories merged seamlessly. Scientists discovered only later in the 19th century that light does not flow through a fluid, magnetism has to do with electrons, and the human body does not have "poles". Yet, in 1815, everything could still be connected to everything, and gravity was just as much a God-given force as mesmerism seemed to be a "scientifically" substantiated force to heal and purify man, animal, and society.

Given his messianic perspective, his impatience with the ongoing meticulous and politically difficult negotiations in the Allied Council about compensation and reparations, Alexander wanted to do greater things, and save France from destruction - as quickly as possible. A series of visits by Bergasse to the Baroness of Krüdener's salon, who came by to demonstrate his scientific talents by means of a sphere (a "melon"), gave him the inspiration he needed. ${ }^{42} \mathrm{An}$ association had to be set up, with himself as its shining middle point, inspired by the spark of the Eternal and with the aim of spreading "anti-revolutionary sentiments and virtues throughout Europe". ${ }^{43}$ In doing so, France, indeed all of Europe, could be purged of the Bonapartist convulsions, and divine order would be restored. The central mesmerizing role would, of course, be appropriated by the Tsar himself, as apotheosis of both his already existing salvific beliefs and this new, semi-scientific creed of radical political mesmerism.

See Robert Darnton, Mesmerism and the End of the Enlightenment in France (Cambridge, MA: 1968); See also Nicolas Bergasse, Considérations sur le magnétisme animal, ou sur la théorie du monde et des êtres organisés, d'après les principes de M. Mesmer (The Hague: 1784). See references in Krüdener's diary, in Ley, Alexander 1er, 131-33. See also Francis Ley, Mme de Krüdener et son temps (Paris: 1961), 475-78. 
On 24 August, this group, consisting of Bergasse, Deliège, a number of royalist allies, including Chateaubriand, and Tsar Alexander himself conspired with Gruner and the Prussians. On 4 September, Gruner set up a meeting with Bergasse, who told him that the Tsar had great faith in Gruner and wanted him to help the Tsar further develop his "religious insights". According to Bergasse, the Tsar was already busy arranging secret meetings in France with an eye to putting "religion and virtue" back on the throne of Europe. The next day, Chateaubriand paid a somewhat overwhelmed Gruner a visit to underscore again the same message, but this time with a concrete political twist: not only the Tsar, but King Louis XVIII too, wanted to dismiss Talleyrand and Fouché as soon as possible because their "depravity and falsity" hindered any recovery of the political body of France. But nothing was going to happen without the support and injunction of the Allies. ${ }^{44}$ In other words, the royalists tried, together with the Russians, to undo the British refusal to go along with Fouchés being dismissed.

Gruner was by now fully convinced of the plan and about setting up such an alliance. He, too, tried to fit the plans of the Tsar, which were just as vague as they were megalomaniac, into his own political mold of forming a centralized police bureaucracy. He asked Hardenberg for instructions, but assured his chancellor that this was exactly what he had argued for earlier: Prussia should make a clear choice for one party in France. He offered to whisk Fouché and Talleyrand from their beds in the middle of the night and send them packing, under the pretext of having "discovered a conspiracy against us" - a conspiracy that will have surfaced in "the secret papers" (that Gruner himself would draw up and plant). The result of which would be "[t]he gratitude of the French family, the glee of the army, the admiration of our people, a lightening of the load for Germany and all of Europe, the preservation of tranquility in the future and the creation of an honorable peace." In addition, Prussia would be "delivered" once and for all. ${ }^{45}$

The constant stream of rumors from his spies and the flattery of Bergasse and Chateaubriand had made Gruner's head spin. Indeed, the elections of 14 and 22 August for the French Chamber of Deputies, the many upheavals and disturbances in the country, and the initial rumors surrounding the final outcomes of the Allies' deliberations had deflated morale and stoked emotions throughout Paris. It also did not help that on 19 August, Talleyrand had blamed the Allied ministers and princes for the deplorable "moral state" of the country; those rising "passions", that soured mood, were all owing to the presence of the

Accounts by Gruner and letter to Hardenberg, 5 September 1815, GStA PK, Nl. Hardenberg $10 a$.

Letter to Hardenberg, 8 September 1815, Hardenberg $10 a$. 
Allied troops, which undermined the authority of the king. ${ }^{46}$ For Gruner, the Tsar and his association, these claims were like adding fuel to the fire. They saw proof of an imminent revolt in his defiance. Their presence and their intervening there was, without a doubt, necessary. Gruner's agents could barely keep up with the many incidents.

As mentioned above, on 10 September, Alexander absolved his military parade, followed the next day by a mass and public prayer. However, the Tsar did not want to leave without performing a final act of liberation. On 12 September, Bergasse's "secret association" came to Gruner again, this time bringing with them a concrete draft for new regulations and laws. According to Bergasse, Tsar Alexander had a "great secret plan to unite all the peoples of the world - irrespective of their diversity — and find the secret way, the most suitable means, to that end". The Tsar and the royalists felt that to save France Prussia had to become involved. The Tsar maintained that the time was now ripe. ${ }^{47} \mathrm{On} 14$ September, Bergasse wrote a first draft of the treaty text for a Holy Alliance to which Alexander added his own words.

All three elements are visible: Christian messianism, enlightened ideas about a fraternal unity of peoples, and a mesmerizing approach that refers to "influence" of the general bond of "fraternity" that connects all peoples and sovereigns, and is inspired by a divine spirit. By means of the principles of this "holy religion", the purification of "human institutions" could be executed, and they would "remedy them from their imperfections" that for so long had "agitated the nations". 48

Even more telling were the concrete measures that accompanied the drafting of the Treaty. From a mesmerist point of view, it was equally important to proclaim unity as to remove as quickly as possible all the obstacles that stood in the way of this fraternity. The way to do this was by triggering a "crisis". The obstacles were, of course, Fouché and Talleyrand, the evil twins responsible for the continuation of revolutionary Bonapartism and ancien régime Macchiavellian politics. On 15 September, the support for deposing Fouché was broad enough; the Chamber now consisted of ultras who made it clear that the current ministry was no longer sustainable. The Prussian King and Russian Tsar agreed entirely, and Wellington, on his own, could no longer

46 Letter from Talleyrand to the Allied Council, 19 August 1815, annex Nr. 89 to the protocols of 20 August, GStA PK III. HA Nr. 1465, 82-83.

47 Report from Gruner to Hardenberg, 12 September 1815, GStA PK, Nl. Hardenberg 10a.

48 Treaty between Austria, Prussia, and Russia, signed at Paris, 26 September 1815, "Holy Alliance," in The Map of Europe by Treaty: Showing the Various Political and Territorial Changes, ed. Edward Hertlet, vol. 1 (London: 1875), 317-20. 
keep Louis XVIII from firing his Bonapartist leftovers. Therefore, Fouché was relieved of his post and sent to Dresden as an ambassador. On 19 September, Talleyrand submitted his resignation. ${ }^{49}$ With the obstacles to the purification of France removed, Gruner was now in charge, with his Allied bureaucracy, and the Tsar could offer his vision for the rejuvenation of France and Europe.

On 22 September, the other Allies received a copy of Alexander's plan. A startled Metternich proceeded to try to tone down the radicalism of the text somewhat. ${ }^{50}$ Yet, on 24 September, the Tsar, the Prussian King Friedrich Wilhelm, and Emperor Franz signed the treaty; as did the English later on. On the morning of 28 September, the Russians left for home. Gruner, the royalists, and their secret association had achieved their goal. ${ }^{51}$

It took another couple of weeks until the crisis was overcome. The greatest source of tension in France remained the imminent announcement of the final peace settlement, and the dread among the French population of an anticipated partitioning - "dismemberment" — of France by the Allies, the potential allocation of Alsace and Lorraine to Prussia and attempts by Austria to put Napoleon II on the throne. ${ }^{52}$ "Tension and ferment" were all around, Gruner wrote, "the 'anti-Bourbon' party holds its breath for the present, the 'royalist party', for the future". ${ }^{3}$ On 20 September, the newspapers published the text of the Second Paris Peace Treaty. It was bad news for France, but less disastrous than feared. France would not be apportioned, but merely cut back to its 1790 borders. The reparations were high, but the king's Prime Minister, the Duke of Richelieu, managed to have them reduced by 100 million francs. One of the greatest sources of unrest was defused: the troops would be evacuated from the French capital immediately, and the humiliating billeting of Prussian soldiers in Parisian parlors and hotels would be over. By the end of November, the Allies' control and military administration of the capital was no longer necessary. Unfortunately for Gruner, his overzealous activities on behalf of the Tsar and his outrageous plans to kidnap and set up Fouché had alienated Hardenberg, Wellington, and the other Allied ministers. He received his last salary as chief of the Allied police in January $1816^{54}$ and was sent to Switzerland as a diplomat.

49 Letter to Talleyrand, 19 September, Allied Council, 19 September 1815, GStA PK III. HA Nr. 1465. Letter from Talleyrand to the Council, 20 September, annex nr. 124, GStA PK III. HA Nr. $1465,177$.

$50 \quad$ See Ley, Alexandre 1er, ${ }^{148-53}$.

51 Report La Coudraye, 8 October 1815, GStA PK, Nl. Hardenberg $10 a$.

$5^{2} 20,22,24,28,29$ September, 6, 8, 11 October, reports from Gruner, reports from La Coudraye to Gruner, GStA PK, Nl. Hardenberg $10 a$.

53 Report Gruner, 20 October 1815, GStA PK, Nl. Hardenberg $10 a$.

54 See "Nachweisungen," in the back of the dossier, GStA PK, Nl. Gruner Nr. 86. 
He died there two years later, a lonely and bitter man. But not before he urged the Swiss cantons - successfully — to agree to accede to the treaty of the Holy Alliance. ${ }^{55}$ Bergasse was rewarded by Charles $\mathrm{X}$ for his royalist loyalty and was appointed Councillor of State, days before Charles was toppled.

This quite astonishing story, pieced together from the Gruner files in the Prussian archives, sheds new light on the Holy Alliance. It serves to underpin the thesis that the Holy Alliance was indeed a strange amalgam of pietist ideas, semi-scientific enlightenment theories, and a strong belief in policing and surveillance bureaucracies. It also suggests a strong link between the Holy Alliance, the removal of Fouché, and the conclusion of the Second Treaty of Paris. By having identified the events and meetings of these hot days in Paris, in September, it becomes clear how the Tsar's convictions about redemption and salvation entered into a chain reaction with novel ideas about reforms and constitutionalism, with Prussian ideas on countering the revolution, mesmerist notions of purification, and very mundane French royalist desires to remove Fouché and Talleyrand from office.

That the Holy Alliance was soon thereafter reduced to a conservative ploy for Metternich was due to the latter's astute political maneuvering and Alexander's preoccupation with domestic uprisings, and of course his early demise in 1825. Since then, the enlightened, semi-scientific mesmerizing, and Prussian reformist, bureaucratic inspirations have been totally overlooked by latter-day historians. Their gaze became too fixed or obsessed with Alexander's circle of mystical and pietist friends, their biases perhaps too much infused by Castlereagh's and Wellington's attempts to ridicule the Tsar and his orthodox beliefs. Obviously, the Tsar himself also forgot about his enlightened mesmerist friends soon enough. Once back in Moscow, and in the conferences of Aachen, Laibach, and Troppau, he let himself be charmed and duped by Metternich into the Austrian Chancellor's more traditional, orthodox, and political reading of the Treaty. Only if we look very closely, traces of the mesmerizing and revolutionary ideals can be found, such as where France is considered to be struck by a "vehement disease", and suffering from revolutionary "convulsions". ${ }^{6}$

55 "De La Coudraye," in Biographie universelle, ancienne et moderne. KM-LAL. Supplement, ed. Louis-Gabriel Michaud and François-Celestin de Loynes, vol. 69 (Paris: 1841), 308; Werner Näf, Zur Geschichte der Heiligen Allianz (Bern: 1928).

56 Castlereagh to Bathurst, 19 October 1818. Foreign Office [FO] 92/35, 138-47. The National Archives, Kew/London. 
In Aachen, in October 1818, Alexander therefore-again-proposed a "medicine" and remedy in the form of a General Alliance and a moral guarantee. ${ }^{57}$ At this time, however, his appeal to the other powers was waning, whereas Metternich's attempts to use Alexander's arguments for stepping up security monitoring and repression at home and interventions abroad were already successful enough to overwhelm the Tsar's more enlightened ideals.

In conclusion, by turning our eyes away from ill-informed and biased interpretations, we may discover that it is time to break the early 19th century away from 2oth-century interpretations of conservatism, and realist, or all too materialist, readings of international relations. What is considered conservatism today, such as Tsar Alexander's mystical and seemingly orthodox ideas, was in fact quite revolutionary and "scientific" in the early 19th century. He was advocating a new political religion, based on ecumenical, brotherly love and equality instead of repression and power politics - as disconnected from other European powerbrokers and ministers and as ill-suited for strategic planning these ideas were in the context of the Balance of Power around 1815 .

If we subscribe to the idea that history is an open process of human willfulness and contingency, and that this openness is filled with ideas, beliefs, and emotions, then it is high time to bring to light the Tsar's ideas that were sometimes far more modern and revolutionary than historians or contemporaries have grasped and let ourselves be mesmerized by them.

\section{Bibliography}

"De La Coudraye," in Biographie universelle, ancienne et moderne. KM-LAL. Supplement, ed. Louis-Gabriel Michaud and François-Celestin de Loynes, vol. 69 (Paris: 1841).

Bergasse, Nicolas, Considérations sur le magnétisme animal, ou sur la théorie du monde et des êtres organisés, d'après les principes de M. Mesmer (The Hague: 1784).

Bertier de Sauvigny, Guillaume de, "Sainte-Alliance et Alliance dans les conceptions de Metternich," Revue Historique 223 (1960), 249-74.

Beugnot, Albertz (ed.), Mémoires du Comte Beugnot, Ancién Ministre (1783-1815) (Paris: 1868).

Chateaubriand, François-René, Mémoires d'outre-tombe, 12 vols. (Paris: 1973 [1849]), vol. 2.

57 Castlereagh to Bathurst, 3 October 1818, FO 92/35, 10-17; Letter from Nesselrode and Capodistrias to Castlereagh and Wellington, 8 October 1818, in WSD, vol. 13, 742-51; "Projet de protocole," 14 October 1828, WSD, vol. 12, 770-73; see also letter to Metternich, 8 October 1818, Österreichisches Staatsarchiv, Haus-, Hof- und Staatsarchiv, Vienna. Staatskanzlei (StK), inv.nr. 17, 33-56. 
Darnton, Robert, Mesmerism and the End of the Enlightenment in France (Cambridge, MA: 1968).

Delfiner, Henry A., "Alexander I, The Holy Alliance and Clemens Metternich: A Reappraisal," East European Quarterly 37 (2003), 127-50.

Eckermann, Johann Peter, "Gespräche mit Goethe," 3. January 1827, in Goethes Gespräche, vol. 6, ed. Woldemar von Biedermann (Leipzig: 189o).

Ford, Clarence (ed.), The Life and Letters of Madame de Krudener (London: 1893).

Ghervas, Stella, Réinventer la tradition: Alexandre Stourdza et l'Europe de la Sainte Alliance (Paris: 2008).

Graaf, Beatrice de, Tegen de terreur: Hoe Europa veilig werd na Napoleon (Amsterdam: 2018).

Graaf, Beatrice de, Fighting Terror after Napoleon. How Europe Became Secure after 1815. (Cambridge: 2020).

Gruner, Justus, Meine Wallfahrt zur Ruhe und Hoffnung oder Schilderung des sittlichen und bürgerlichen Zustandes Westphalens am Ende des 18. Jahrhunderts (1802).

Gruner, Justus, Versuch über die rechte und zweckmäßigste Einrichtung öffentlicher Sicherheitsinstitute und deren Verbesserung (1802).

Hertlet, Edward (ed.), The Map of Europe by Treaty: Showing the Various Political and Territorial Changes, vol. 1 (London: 1875).

Holborn, Hajo, "Russia and the European Political System," in Russian Foreign Policy: Essays in Historical Perspective, ed. Ivo J. Lederer (New Haven, CT: 1962), 377-409.

Houssaye, Henri, 1814 (Paris: 1888).

Kissinger, Henry, Diplomacy (New York: 1994).

Ley, Francis, Alexandre $1^{\text {er }}$ et sa Sainte-Alliance (1811-1825). Avec des documents inédits (Paris: 1975).

Ley, Francis, Mme de Krüdener et son temps (Paris: 1961).

Lok, Matthijs, "The Congress of Vienna as a Missed Opportunity: Conservative Visions of a New European Order after Napoleon," in Securing Europe after Napoleon: 1815 and a New European Security Culture, ed. Beatrice de Graaf, Ido de Haan, and Brian Vick (Cambridge: 2019), 56-71.

McNally, Thomas, "Das Rußlandbild in der Publizistik Frankreichs zwischen 1814 und 1843," Forschungen zur Osteuropäischen Geschichte 6 (1958), 82-170.

Melnikova, Liubov, “Orthodox Russia against 'Godless' France: The Russian Church and the 'Holy War' of 1812," in Russia and the Napoleonic Wars, ed. Janet M. Hartley, Paul Keenan, and Dominic Lieven (Basingstoke: 2015), 179-95.

Menger, Philipp, Die Heilige Allianz: Religion und Politik bei Alexander I. (1801-1825) (Stuttgart: 2014).

Metternich, Richard (ed.), Memoirs of Prince Metternich, 1773-1835 (New York: 1880-82).

Mikhailofsky-Danilefsky, A., History of the Campaign in France in the Year 1814 (London: 1839).

Näf, Werner, Zur Geschichte der Heiligen Allianz (Bern: 1928). 
Rey, Marie-Pierre, Alexander I: The Tsar who Defeated Napoleon (DeKalb: 2012).

Shapiro, Barry M., Traumatic Politics: The Deputies and the King in the Early French Revolution (University Park, TX: 2009).

Taylor, Alan John Percivale, The Struggle for Mastery in Europe, 1848-1918 (Oxford: 1954) Wellesley, Arthur (ed.), Supplementary Dispatches and Memoranda of Field Marshal Arthur Wellesley, ist Duke of Wellington, vol. 11 (London: 1864).

Zeisler, Kurt, "Justus von Gruner: Eine biographische Skizze," in Berlin in Geschichte und Gegenwart, ed. Werner Breunig and Uwe Schaper (Berlin: 1994), 81-105. 